\title{
Two-way migration of Lychnis wilfordii caused by the circular landform of Japan-Korea-northeast China-Russian Far East region and its suggestion for conservation in northeast Asia
}

Saya Tamura ${ }^{\mathrm{a}, \mathrm{b}}$, Myounghai Kwak ${ }^{\mathrm{c}}$, Goro Kokubugata ${ }^{\mathrm{d}}$, Chan-ho Park ${ }^{\mathrm{c}}$, Byoung-Yoon Lee ${ }^{\mathrm{c}}$, Tomoko Fukuda ${ }^{\mathrm{e}}$, Ekaterina Petrunenko ${ }^{\mathrm{f}}$, Inna Koksheeva ${ }^{\mathrm{f}}$, Elena Pimenova ${ }^{\mathrm{f}}$, Pavel Krestov ${ }^{\mathrm{f}}$, Svetlana Bondarchuk $^{\mathrm{g}}$, Jin-Shuang Ma ${ }^{\mathrm{h}}$, Hai-Cheng Zhou ${ }^{\mathrm{i}}$, Hayato Tsuboi ${ }^{\mathrm{j}}$, Yoko Nishikawa ${ }^{\mathrm{k}}$, Takashi Shimamura ${ }^{\mathrm{k}}$, Hiroko Fujita ${ }^{1}$, Koh Nakamura ${ }^{1}$ *

a Division of Environmental Resources, Graduate School of Agriculture, Hokkaido University,

Sapporo 060-8589, Japan

b Japan Wildlife Research Center, Tokyo 130-8606, Japan

c Plant Resources Division, National Institute of Biological Resources, Incheon, Republic of Korea

d Department of Botany, National Museum of Nature and Science, Tsukuba, Ibaraki 305-0005, Japan

e College of Liberal Arts and Sciences, Mie University, Tsu 514-8507, Japan

f Botanical Garden-Institute, Far Eastern Branch of the Russian Academy of Sciences, Makovskii Str.

142, Vladivostok, 690024, Russia

g Sikhote-Alin State Nature Biosphere Reserve, Ministry of Nature Resources and Environment,

Terney 692150, Russia

h Shanghai Chenshan Plant Science Research Center, Chinese Academy of Science / Chenshan

Botanical Garden, Chen Hua Road, Songjiang District, Shanghai, 201602, China

i Conservation Center of Management Bureau of Changbai Mountain, Antu 133613, Jilin, China

j Hakuba-Goryu Alpine Botanical Garden, Hakuba 399-9211, Japan

k Institute of Environmental Sciences, Hokkaido Research Organization, Sapporo 060-0819, Japan

1 Botanic Garden, Field Science Center for Northern Biosphere, Hokkaido University, Sapporo

060-0003, Japan. Correspondence: kohnakamur@gmail.com

\begin{abstract}
In northeast Asia, substantial portion of the floras, including endangered species, are shared among its component countries in the continental, peninsula, and island parts largely through Quaternary migration. To effectively conserve nationally endangered plants in Northeast Asia, transnational conservation studies are vitally needed. Lychnis wilfordii (Caryophyllaceae) has disjunct distribution in Russian Far East (Primorsky Krai), northeast China (Jilin), Korea (Gangwon-do) and Japan (Hokkaido, Aomori, Nagano), surrounding the sea, and this is designated as an endangered species in Japan and Korea. Population genetic and molecular dating analyses were conducted 1) to elucidate geographic genetic structure covering the species range, 2) to test possible scenarios of migration,
\end{abstract}


and 3) to develop logical plans for effective conservation. Population genetic analyses indicated the continent and peninsula parts (north and south Primorsky Krai, Jilin, and Gangwon-do) had higher genetic diversity compared to those in the Japanese Archipelago (Hokkaido and Nagano). Five genetically distinct groups were recognized, namely, Nagano, Gangwon-do, Jilin, north and south Primorsky Krai plus Aomori, and Hokkaido. Genetic distance between Hokkaido and Nagano was larger than between Hokkaido and north Primorsky Krai, and between Nagano and Gangwon-do, crossing national borders and the natural barrier of the sea. Considering these results, L. wilfordii likely migrated from the Asian continent to the Japanese Archipelago using two routes: north route from Russian Far East to Hokkaido and Aomori, and south route from the Korean Peninsula to Nagano. Based on molecular dating, migration from the continent to the islands likely occurred from the middle Pleistocene to the Holocene. For effective conservation of L. wilfordii, Hokkaido and Nagano populations should be distinguished as different evolutionary significant units, although these two regions belong to the same country, because Hokkaido and Nagano populations are at the different ends of the two migratory routes based on the migration scenario.

\section{INTRODUCTION}

Flora of northeast Asia, here defined as Japan-Korea-northeast China-Russian Far East region, is rich and occupies a unique position in global plant diversity, containing many relic and neo-endemic plant lineages (Good, 1974; Maekawa, 1974; Takhtajan, 1986; Wu \& Wu, 1996; Tang \& Ohsawa, 2002). At the same time, considerable portions of the floras of the component countries (ca. 10-25\% in each country) are currently threatened or on the verge of extinction due to extrinsic factors (habitat loss and degradation, overexploitation, climate change) as well as intrinsic ones (limited habitat due to unique ecological demands) (Biodiversity working group of China council for international cooperation on environment and development, 2004; Community of natural resources and environment conservation of Sakhalin state et al., 2005; Administration of Kamchatka region et al., 2007; Administration of Primorsky Krai krai et al., 2008; National institute of biological resources, 2014; Ministry of the Environment, Government of Japan, 2015). These countries share substantial portion of the floras (Good, 1974; Takhtajan, 1986), and plants designated as endangered species in one country are not all national endemics but distributed in neighboring countries as endangered or non-endangered species (Kokubugata, 2016). Nevertheless, conservation studies on endangered plants in this region are usually confined to one country (Jin et al., 2003; Washitani et al., 2005; Hu et al., 2010; Jae \& Sungwon, 2016) and the progress of plant conservation in northeast Asia is impeded by national borders. Rare examples of pan-northeast Asian studies include an attempt to compile an integrated red list of East Asian plants, including Russian Far East (Kokubugata, 2016). For endangered plants distributed across national borders, conservation of populations in one country but not in others is ineffective if those populations share the same gene 
pool because this would lead to genetic diversity loss in "conserved" populations once nonconserved ones are lost. To effectively conserve nationally endangered plants in northeast Asia, that often have conspecific populations abroad, transnational conservation studies are vitally needed.

A unique feature of endangered plant species in northeast Asia is its disjunct distribution in the continental part (northeast China and Russian Far East), the Korean peninsula, and the islands (in particular, the Japanese Archipelago and Sakhalin), encircling a geographic barrier of the sea. Geohistorically, due to Quaternary sea level fluctuations, the Japanese Archipelago was repeatedly connected to the Eurasian continent with landbridges via Sakhalin until the Last Glacial Maximum in the north (Pietsch et al., 2003) and via the Korean peninsula until the late Pleistocene in the south (Ohsima, 1990), forming a continuous circular landform. Many plant species migrated from the continent to the Japanese Archipelago via these landbridges during Quaternary, as revealed by molecular studies (e.g. alpine plants: Fujii \& Senni, 2006; Ikeda et al., 2008, trees and shrubs: Okaura et al., 2007; Aizawa et al., 2007, 2009, herbs: Lihová, et al., 2010; Kikuchi et al. 2010, 2013). These studied plants are mostly common species, and few studies focused on endangered plants for the conservation. Elucidating genetic legacy from migration/range expansion in the landform of northeast Asia can contribute substantially to increase the effectiveness of conservation planning based on genetic profile of populations because it is not only the result of population-genetic processes in ecological time scale. Broad spatial and temporal scale studies are needed for endangered plants in northeast Asia.

Lychnis wilfordii (Regel) Maxim. (Caryophyllaceae) is one of such endangered species that has disjunct distribution in northeast Asia surrounding the sea, i.e. in Russian Far East (Primorsky Krai), northeast China (Jilin), Korea (Gangwon-do) and Japan (Hokkaido, Aomori, Nagano) (Figs. 1, 2; Lu et al., 2001; Aomori prefecture, 2010; National Institute of Biological Resources, 2014; Tamura et al., 2016; Kadota, 2017). This species grows in wet meadows and at wet woodland edges. The numbers of individuals and habitats of this species are decreasing due to ecological succession, exploitations, and overcollection for horticultural purposes, and this species is designated as an endangered species in Japan and Korea (National Institute of Biological Resources, 2014; Ministry of the Environment, Government of Japan, 2017). In northeast China, it is not designated as an endangered species but treated as a rare species. In Russian Far East, on the other hand, this is a common species and there are larger number of individuals and populations.

There are a few conservation studies of this species in Japan (Tamura et al. 2016) and Korea (Jae $\&$ Sungwon 2016), the latter focusing on conservation activities in Korea. The former study (Tamura et al., 2016) conducted conservation genetic analysis of Japanese populations of $L$. wilfordii using a limited number of microsatellite markers and revealed that Hokkaido populations (northernmost populations of Japan) are distinct from Nagano populations (southernmost populations); but no samples were used from Korea, northeast China or Russian Far East and species range-wide genetic 
structure was not elucidated.

In this study we conducted population genetic analyses using 17 nuclear microsatellite (nSSR) markers, and molecular dating using cpDNA sequence data. The aims of this study are 1) to elucidate geographic genetic structure of $L$. wilfordii covering the species range, 2) to test possible scenarios of migration in northeast Asia, and 3) to develop logical plans for effective conservation based on geographic genetic structure and ecological information.

\section{MATERIALS AND METHODS}

\section{Materials}

Lychnis wilfordii is a monoecious perennial herb. This is a diploid species (Kruckeberg, 1960) and reproduces sexually with seeds and asexually with rhizomes (Kozhevnikov et al., 2015; Tamura et al., 2016). Although the seeds usually disperse by gravity, they have many hooked spines on the surface (Nakayama et al., 2006) and can be dispersed long-distance by animals.

This species is designated as endangered species in Japan and Korea not only at national but also at prefectural levels: in Japan, Cr (critically endangered), A (most important and rarest wild species), and EN (endangered) in Hokkaido, Aomori, and Nagano prefectures, respectively (Hokkaido prefecture, 2001, 2016; Aomori prefecture, 2010; Nagano prefecture, 2014, 2017). The numbers of individuals/populations are estimated in Hokkaido (339 individuals in 10 populations, author's unpublished data), Aomori (a few individual in one population; Aomori prefecture, 2010), Nagano (ca. ten populations; Ministry of the environment of Japan, 2015), and Korea $(<300$ individuals in three populations; National Institute of Biological Resources, 2014).

Samples were collected covering the species range in northeast Asia, where geographically isolated seven regions are recognized, i.e., Hokkaido, Aomori, Nagano of Japan, Gangwon-do of Korea, Jilin of China, and south Primorsky Krai and north Primorsky Krai of Russian Far East (Table 1). Field collection was conducted in Hokkaido (103 individuals/10 populations), Nagano (55/6), Gangwon-do (65/3), Jilin (98/10), south Primorsky Krai (57/4), and north Primorsky Krai (49/3) (Table 1; Fig 2). In each population, samples were collected > $50 \mathrm{~cm}$ apart from each other not to collect the same clones. In addition, for recently extinct populations in Karuizawa, Nagano prefecture of Japan (Hara et al., 1974; Ikeda, 1997), we utilized herbarium specimens (three individuals) and $e x$-situ collection of a botanic garden (two individuals) (Table 1). The only known population in Aomori prefecture of Japan is in a Japanese military base and inaccessible, and a herbarium specimen was used. In total, 433 individuals from 38 populations were studied from the four countries. In cpDNA sequence analysis, a portion of these samples were used. Voucher specimens of our collection were deposited in the herbaria of Botanic Garden, Hokkaido University (SAPT) and National Institute of Biological Resources (KB). 


\section{DNA extraction, nSSR genotyping, cpDNA sequencing}

Total genomic DNA was extracted from silica gel-dried leaves, using the CTAB method (Doyle \& Doyle, 1987). In the nSSR analysis, DNA samples were genotyped for 17 nSSR loci by using primer pairs developed for L. wilfordii (Kim et al. 2018). PCR was conducted using forward primers attached M13-tail (5'-GTA AAA CGA CGG CCA GT-3'), M13 primer labeled with the fluorescent dyes 6-FAM, VIC, NED, or PET (Applied Biosystems, Foster City, California, USA), and reverse primers. PCR reactions were performed in $20 \mu \mathrm{l}$ total volume with the following reagents: ca. $10 \mathrm{ng}$ genomic DNA, 1 unit Taq DNA polymerase master mix (Ampliqon, Rødovre, Denmark), $0.3 \mu 1$ M13-tailed forward primer, $0.6 \mu 1$ reverse primer, $0.6 \mu 1$ fluorescent-labeled M13 primer (Table 2) and $2 \%$ dimethyl sulphoxide (DMSO). The PCR cycle conditions were as follows: initial denaturation at $95{ }^{\circ} \mathrm{C}$ for $10 \mathrm{~min} ; 35$ cycles of denaturation at $95{ }^{\circ} \mathrm{C}$ for $30 \mathrm{sec}$, annealing at $\mathrm{Ta}{ }^{\circ} \mathrm{C}$ (Table 2) for $30 \mathrm{sec}$, and elongation at $72{ }^{\circ} \mathrm{C}$ for $30 \mathrm{sec}$; and final extension at $72{ }^{\circ} \mathrm{C}$ for $7 \mathrm{~min}$. For Lw80 marker, 2nd PCR (10 cycles) was conducted using $0.5 \mu 1$ 1st PCR product (amplified without using fluorescent dye) diluted with sterilized water by three times. The PCR product size was measured with the size standard 600LIZ using an ABI Prism 3130 DNA analyzer (Applied Biosystems, Foster City, CA, USA) and Peak Scanner software v1.0 (Thermo Fisher Scientific, MA, USA).

For DNA sequencing, eight cpDNA regions (Table 3) were PCR amplified. PCR reactions were performed in $25 \mu \mathrm{l}$ total volume with the following reagents: ca. $10 \mathrm{ng}$ genomic DNA, 1unit Taq DNA polymerase master mix (Ampliqon), $1 \mu 1$ each primer and $4 \%$ DMSO. The PCR cycle conditions were $95{ }^{\circ} \mathrm{C}$ for $4 \mathrm{~min}, 30$ cycles of $94{ }^{\circ} \mathrm{C}$ for $50 \mathrm{sec}$, Ta ${ }^{\circ} \mathrm{C}$ (Table 3) for $50 \mathrm{sec}$ and $72{ }^{\circ} \mathrm{C}$ for $40 \mathrm{sec}$, and final extension at $72{ }^{\circ} \mathrm{C}$ for $10 \mathrm{~min}$. The PCR fragments were purified with isopropanol precipitation. Purified PCR fragments were used as template for cycle sequencing reactions with the same primers used in the PCR, and direct sequencing was performed on an ABI Prism 3130 DNA analyzer.

\section{Analyses based on nSSR data}

\section{Genetic profile}

The following diversity and inbreeding parameters were computed for populations $(n \geq 4)$ and each of the six regions (excluding Aomori) using FSTAT 2.9.3.2 (Goudet, 2002): the total number of detected alleles $\left(N_{\mathrm{A}}\right)$, allelic richness $(R \mathrm{~s}$, number of alleles independent of sample size, standardizes for the smallest number of individuals per unit using rarefaction. For populations/regions, it was rarefied to $4 / 15$ samples with $15 / 16$ markers excluding markers unamplified in six populations/one region), genetic diversity $(H \mathrm{~s})$ and the average inbreeding coefficient $\left(F_{\mathrm{IS}}\right)$ across all the loci. For $F_{\mathrm{IS}}$, the significance of departures from zero was tested with 10200 randomizations. 


\section{Population genetic structure}

Population genetic structure was analyzed using a Bayesian clustering algorithm implemented in STRUCTURE 2.3.4 (Pritchard et al., 2000, 2010), which probabilistically assigns individuals to clusters based on their multi-locus genotypes by minimizing Hardy-Weinberg and linkage disequilibria. To estimate the most probable number of clusters $(K)$, we first conducted a preliminary analysis using about half of the samples (237 samples) from the whole species range, changing $K$ from 1 to 20, and the optimal $K$ was suggested to be below 10 . We therefore set the highest $K=10$, which is greater than the number of the geographically isolated regions (i.e., Hokkaido, Aomori, Nagano, Gangwon-do, Jilin, south Primorsky Krai, and north Primorsky Krai). The analysis was performed assuming the admixture model and correlated allele frequencies among clusters with default parameter settings. Twenty independent runs for each $K$ were carried out to verify the consistency of results, with 2000000 MCMC replications after a burn-in length of 500000 replications. To estimate the most probable $K$, the statistic $\Delta K$ based on the second-order rate of change of the posterior probability of the data $\ln P(D)$ with respect to $K$ (Evanno et al., 2005) was computed as average over 20 runs using STRUCTURE HARVESTER (Earl \& vonHoldt, 2012). For the value of $K$ selected, the symmetric similarity coefficient (SCC: $H^{\prime}$ ) between all pairs of 20 runs, calculated with CLUMPP 1.1.2 (Jakobsson \& Rosenberg, 2007), was > 0.45, and membership coefficients $(Q)$ of each individual was calculated as average over 20 runs using CLUMPP. The $Q$ values were visualized using DISTRUCT (Rosenberg, 2004).

Genetic distance $D_{\mathrm{A}}$ (Nei et al., 1983) among all 38 populations and among six regions (except Aomori with only one sample) were calculated based on the nSSR data using Populations 1.2.32 (Langella, 2010) and subjected to principal coordinates analysis (PCoA) using GenALEx 6.5 (Peakall \& Smouse, 2012).

\section{Analyses based on cpDNA data MRCA dating}

The sequences were aligned using GeneStudio 2.2 (GeneStudio Inc., Suwanee, Georgia) and then adjusted manually using BioEdit v7.2.5 (Hall, 1999). The age of the most recent common ancestor (MRCA) was estimated using BEAST 1.8.4 (Drummond et al., 2012). The appropriate evolutionary model for the cpDNA data was SYM+G, as selected using PAUP* ver. 4.0b10 (Swofford, 2002) and MrModeltest 2.3 (Nylander, 2008), based on the Akaike Information Criterion (AIC). An empirical base frequency and a lognormal relaxed clock rate were used. For molecular dating, a previous study used a split between the subfamilies Alsinoideae and Caryophylloideae as a fossil-calibrated node to estimate the age of the MRCA of the genus Lychnis, using a coding region of matK (Gizaw et al., 2016); but a substitution rate for non-coding cpDNA region is not available for this group. We therefore referred to previous reports on non-coding cpDNA substitution rates (per site per year) for other herbaceous plants, most of which have a minimum generation time of 1-3 years (minimum 
value $=1.30 \times 10^{-9}$, mean value $=4.77 \times 10^{-9}$, maximum value $\left.=8.24 \times 10^{-9}\right)$ (Richardson et al. , 2001). To obtain the similar distribution to that of these reported values, a gamma distribution prior was employed for clock rate with an initial value of $4.77 \times 10^{-9}$, a shape value of 4.095 , a scale value of $9.2 \times 10^{-9}$ and an offset value of 0.00 , which had the median of $3.47 \times 10^{-9}$ and $95 \%$ range of the distribution between $1.05 \times 10^{-9}$ and $8.20 \times 10^{-9}$. A starting tree was generated using random starting tree option. Markov chain Monte Carlo (MCMC) chain length was 200 million steps and parameter values were logged every 1000 steps. The initial $10 \%$ of the sampled parameter values were discarded as burn-in. Convergence of MCMC algorithms and effective sample size (ESS > 500) for each parameter were checked using TRACER 1.6 (Rambaut et al., 2013). A maximum clade credibility tree was estimated with a posterior probability limit $(P P)$ of 0.5 by TreeAnnotator ver. 1.8.4 (Drummond et al., 2012), and the estimated age of the MRCA (mean age and $95 \%$ highest posterior density [HPD] interval) was checked on FigTree ver. 1.4.2 (Rambaut, 2014).

\section{RESULTS}

\section{Analyses based on nSSR data}

\section{Genetic profile}

The genetic diversity estimates at region level indicated comparatively lager values in the continent and peninsula, i.e., north Primorsky Krai $(R \mathrm{~s}=3.68, H \mathrm{~s}=0.45)$, south Primorsky Krai $(4.69,0.60)$, Jilin (5.72, 0.59), and, Gangwon-do (3.72, 0.60) than in regions in Japan, i.e., Hokkaido (1.49, 0.14) and Nagano $(1.8,0.19)$ (Table 1$). F_{\text {IS }}$ values ranged from -0.56 to 0.75 at population level and 0.59 to 0.92 at region level (Table 1). $F_{\text {IS }}$ values were significantly different from zero in most populations (Table 1).

\section{Population genetic structure}

In the STRUCTURE analysis, $K=3$ and 5 were supported as the most and second probable numbers of clusters by $\Delta K$ (Fig. S). When $K=3$ (Fig. 3), Hokkaido (populations no. 1-10) and Jilin (no. 22-31) almost exclusively belonged to the blue and yellow clusters, respectively. Nagano (no. 12-18) chiefly belonged to the red cluster, but secondarily to the blue cluster. Gangwon-do populations belonged chiefly to the red (no. 19) or yellow (no. 20,21) clusters and secondarily vice versa. South and north Primorsky Krai populations primarily belonged to the red (no. 32, 35), yellow (no. 33, 34, 36), and blue (no. 37, 38) clusters but also belonged to the other two clusters with varying degrees. When $K=5$, the genetic difference among the regions became clearer than $K=3$. In detail, the populations from Nagano (excluding no. 18), Gangwon-do (excluding no. 19), Jilin, and Hokkaido almost entirely belonged to the red, pink, yellow, and blue clusters, respectively. The majority of south Primorsky Krai (no. 33-35), north Primorsky Krai (no. 36-38), and Aomori (no. 11) populations mainly belonged to the green cluster, while partly belonged to the yellow, pink 
and/or blue clusters. The result showed non-negligible $Q$ values for more than two clusters in Nagano (no. 18, mainly to the red but partly to the green and pink), Gangwon-do (no. 19, mainly to the green and pink but partly to the yellow and blue), and south Primorsky Krai (no. 32, mainly to the pink but partly to the green and yellow).

$D_{\mathrm{A}}$ genetic distance among populations ranged from 0 to 1.00 , with the mean of 0.67 (Table $\mathrm{S}$ ). The value was large comparatively (here defined as $\geq 0.95$ ) between Nagano (no. 17) and Jilin (no. 22, 24, 26, 28 and 30) $\left(D_{\mathrm{A}}=0.95-1.00\right)$, and Gangwon-do (no. 19) and Jilin (no. 22, 23, 26 and 27) $\left(D_{\mathrm{A}}=0.96-0.97\right)$, on the other hand the value was small comparatively (here defined as $\left.\leq 0.05\right)$ between populations in Hokkaido (population no. 1 and 5, $D_{\mathrm{A}}=0.05 ; 2$ and 4, 0.00; 2 and 5, 4 and 5, 0.01), and in Nagano (no. 14 and 15, 0.00). The PCoA plots based on $D_{\mathrm{A}}$ is shown (Fig. 4). The first and second axes extracted $28.39 \%$ and $27.43 \%$ of the total genetic variation. Plots of populations clustered roughly corresponded to the five groups, i.e., Nagano (no. 12-17), Gangwon-do (no. 19-21), Jilin (no. 22-31), south and north Primorsky Krai (no. 32-38), and Hokkaido plus Aomori (no. 1-11); note that one Nagano population (no. 18) was exceptional and plotted closer to Gangwon-do populations. The plots indicated genetic proximity between Nagano and Gangwon-do populations, between south and north Primorsky Krai, and Hokkaido plus Aomori populations, and among Jilin, Gangwon-do, and south and north Primorsky Krai populations, whereas Hokkaido and Nagano populations were plotted distantly. $D_{\mathrm{A}}$ genetic distance among the six regions (excluding Aomori with only one sample; Table 4) was comparatively large (here defined as $>0.70$ ) between Hokkaido and Gangwon-do $\left(D_{\mathrm{A}}=0.83\right)$, Nagano and Jilin (0.81), Nagano and north Primorsky Krai (0.74), and Hokkaido and Nagano (0.70); whereas it was comparatively small $(<0.40)$ between Hokkaido and north Primorsky Krai (0.34) and north Primorsky Krai and south Primorsky Krai (0.39). The PCoA plots based on $D_{\mathrm{A}}$ for these six regions is shown (Fig. 5). The first and second axes extracted $40.69 \%$ and $35.19 \%$ of the total genetic variation. The plots showed the genetic proximity among Jilin, south Primorsky Krai, and north Primorsky Krai populations, and between north Primorsky Krai and Hokkaido populations. Hokkaido and Nagano were again plotted distantly.

\section{MRCA dating based on cpDNA}

The aligned length of cpDNA data was $4693 \mathrm{bp}$, where only one single nucleotide difference was found between Chinese samples and the other ingroups. Thereby, the data provided little resolution within the ingroup clade $(P P=1)$. The Bayesian molecular dating based on cpDNA estimated the mean age of the MRCA of L. wilfordii as 0.85 million years (Myr), i.e., the base of the Late Pleistocene, and $95 \%$ highest posterior density (HPD) interval as 0.005-0.42 Myr, i.e., the middle Pleistocene to the Holocene.

\section{DISCUSSION}




\section{Geographic genetic structure}

The population genetic analyses using 17 nSSR markers were conducted to elucidate geographic genetic structure of $L$. wilfordii covering the whole species range in northeast Asia. Based on the results of the STRUCTURE $(K=5)$ and PCoA analyses, five genetically distinct groups were recognized, namely, Nagano, Gangwon-do, Jilin, north and south Primorsky Krai plus Aomori, and Hokkaido (Figs. 3, 4). In the PCoA (Fig. 4), Hokkaido populations are clustered in the proximity to Aomori and north Primorsky Krai populations of the continent but away from Nagano populations of the same Japanese Archipelago. On the other hand, Nagano populations are plotted close to Gangwon-do populations of the Korean peninsula, and Gangwon-do populations are to south Primorsky Krai populations. These close relationships also represented at STRUCTURE (Fig. 3), which was indicated non-negligible $Q$ values for more than two clusters at population no. 18 in Nagano, 19 in Gangwon-do, and 32 in south Primorsky Krai. PCoA plots of Jilin populations are close to those of south Primorsky Krai populations. The PCoA plots of the five genetic groups roughly correspond to their geographic distribution in northeast Asia (Figs. 2, 4). This is more evident in the PCoA at the regional level (Fig. 5). This suggests that the geographic genetic structure was formed reflecting migratory history of the species, as discussed later.

It is contrasting that in the continent and the peninsula, populations of the same country (i.e., Korea, northeast China, or Russian Far East) clustered together and formed the genetically distinct group, whereas in the archipelago, the Japanese populations did not cluster together but highly differentiated between Hokkaido plus Aomori and Nagano (Figs. 4, 5). It is worth to note that the genetic distance between Hokkaido and Nagano $\left(D_{\mathrm{A}}=0.70\right.$, Table 4$)$ was larger than between Hokkaido and north Primorsky Krai (0.34) and between Nagano and Gangwon-do (0.67) crossing national borders and the natural barrier of sea. Although the genetic difference between Hokkaido and Nagano was recognized in the previous study (Tamura et al., 2016), the present study covering the whole species range revealed that the genetic difference between Hokkaido and Nagano are relatively large among regions of the other countries. What the geographic genetic structure revealed here suggests for the conservation of $L$. wilfordii is discussed below.

\section{Possible scenario of migration}

To discuss the migratory history of L. wilfordii in northeast Asia, its ancestral area should be elucidated. The nSSR analysis indicated that the genetically recognized groups in the continent and peninsula parts (north and south Primorsky Krai, Jilin, and Gangwon-do) had higher genetic diversity compared to those in the Japanese Archipelago (Hokkaido and Nagano) (Table 1). In general, progenitor populations in ancestral areas have higher genetic diversity than derivative populations due to founder effect in the latter (Frankham, 1996; Hewitt, 1996; Ibrahim et al., 1996), although this pattern can be disrupted by other population genetic processes such as bottleneck 
events in ancestral populations, gene flow/recurrent migration to derivative populations, and natural selection (e.g. Hiramatsu et al., 2001; Tremetsberger et al., 2003; Morrell et al., 2003). Additionally, genus Lychnis is distributed widely from Europe, via Africa, to northeast Asia (Lu et al., 2001), and the genus have likely expanded its range from the Eurasian continent to Africa (Popp et al., 2008; Gizaw et al., 2016), suggesting that Eurasian species are relatively old in the genus. Lychnis wilfordii has the phylogenetically closest species in the Asian mainland (Ullbors, 2008). Based on these data and the circumstantial evidence, it is highly likely that the Asian continent is the ancestral area of $L$. wilfordii and the species expanded to the Japanese Archipelago. As discussed above, in the PCoA based on $D_{\mathrm{A}}$ distance (Figs. 4, 5), the plots of Nagano, Gangwon-do, Jilin, north Primorsky Krai, south Primorsky Krai, Aomori, and Hokkaido roughly corresponded to their geographic distribution in northeast Asia (Fig. 2), suggesting that the geographic genetic structure was formed reflecting migratory history of the species. Considering that Hokkaido and Aomori populations are genetically close to north Primorsky Krai populations and that Nagano populations are to Korean populations, $L$. wilfordii likely migrated from the Asian continent to the Japanese Archipelago using two routes: north route from Russian Far East to Hokkaido and Aomori, and south route from the Korean Peninsula to Nagano.

The age of the MRCA of L. wilfordii was estimated as $0.085 \mathrm{Myr}(0.005-0.42 \mathrm{Myr})$ and this corresponds to the middle Pleistocene-the Holocene. During the Last Glacial Maximum (LGM), the climate was cooler and the sea level was ca. $85-130 \mathrm{~m}$ below the present level, and the huge ice sheets developed in high-latitude areas of the Northern Hemisphere and Antarctic (Tsukada, 1983; Oba \& Irino, 2012). It was suggested that there was landbridge formation between the Korean Peninsula and southwestern Japan during the Pleistocene including the complete closure of the strait and the inundated landbridge (Oba et al., 1991; Millien-Parra \& Jaeger, 1999; Kim et al., 2000; Lee \& Nam, 2003; Lee et al., 2008; Oba \& Irino, 2012). Many studies suggested that various plant lineages migrated using the landbridge between the Korean Peninsula and southwestern Japan (e.g. Aizawa et al., 2007, 2009; Kikuchi et al., 2010, 2013; Qi et al., 2012). It is highly likely that the south-route migration of $L$. wilfordii from Korea to Japan was facilitated by that landbridge, even if it was split by a narrow strait. On the other hand, concerning the north route, there was no direct land connection between the continental part of Russian Far East and Hokkaido, although Sakhalin Island connected them, during the Pleistocene (Minato \& Ijiri, 1984, Yasuda, 1984; Oba et al., 1991; Oba \& Irino, 2012). However currently L. wilfordii is not distributed in Sakhalin (Institute of biology and soil science, Russian academy of sciences, Far Eastern branch, 1996), and it would not be parsimonious or rational to postulate its extinction in Sakhalin because L. fulgens, that sometimes grows sympatrically with L. wilfordii in Primorsky Krai (Institute of biology and soil science, Russian academy of sciences, Far Eastern branch, 1996; author's observation), is found in Sakhalin (Sugawara, 1975). This means that $L$. wilfordii likely expanded the distribution via the north route by 
long-distance dispersal. Bird dispersal is a highly probable scenario considering the seed morphology having many hooked spines on the surface (Nakayama et al., 2006). Bird dispersal may also have happened between Gangwon-do (no. 19) and south Primorsky Krai (no. 32, 33 and 34), for which genetic affinity was indicated by the STRUCTURE and PCoA analyses despited the large geographic distance.

The north and south migratory routes has long been recognized to have played a fundamental role in shaping the flora of the Japanese Archipelago (Good, 1974; Maekawa, 1974; Takhtajan, 1986). The migration of $L$. wilfordii via both the north and south routes, however, is a rare example of two-way migration by a single species. Previously, this was revaled by molecular data only for a northeast Asian spruce Picea jezoensis (Aizawa et al., 2007, 2009), although it was hypothesized, but without verification, in several plant species (Lihová et al., 2010; Kikuchi et al., 2010, 2013). The connection between the circular landform of Japan-Korea-northeast China-Russian Far East region and the potential two-way migration of a species is an interesting issue for further study in conservation biology as well as biogeography in northeast Asia.

\section{Logical plans for effective conservation}

In conservation biology, conservation units (evolutionary significant units, ESUs, management units, MUs) are defined for effective conservation practice. Based on the geographic genetic structure, it became clear that there are five genetically distinct groups in L. wilfordii, i.e., Hokkaido, Nagano, Korea, northeast China, and Russian Far East. In particular, Hokkaido and Nagano populations should be distinguished as different ESUs because Hokkaido and Nagano populations are at the different ends of the two migratory routes based on the migration scenario, although these two regions belong to the same country. Outbreeding depression can happen as a result of gene flow between diverged populations, especially when the species have limited dispersal ability and populations are adapted to local environments (Frankham et al., 2002). The dispersal of this species between the regions (i.e., Hokkaido, Nagano, Korea, northeast China and Russian Far East) is limited. Its habitats are wetlands and environments are similar among populations across the species range (Shimizu, 1997; Lu et al., 2001; National Institute of Biological Resources, 2014; Tamura et al., 2016), however, climatic conditions, specifically temperature in winter and day length, are different among the regions at different latitudes. Therefore the crossing between ESUs can potentially cause outbreeding depression. It is worth to note that there found a slight morphological difference between Hokkaido and Nagano populations; the leaf edge is flat in the former but waved in the latter. More detailed morphological studies, together with cross-fertility tests of the genetic groups recognized in the present study, are vitally needed to further improve conservation planning.

Lychnis wilfordii is the target of conservation activities in Japan and Korea, but in northeast China and Russian Far East, no special conservation measures are currently taken for L. wilfordii 
because this species is not designated as an endangered species in China or Russia. This study revealed the five genetically distinct groups and defined the ESUs of Hokkaido and Nagano. Considering that the continental populations are potentially migratory source for the island populations in an evolutionary time scale, transnational conservation of $L$. wilfordii in northeast Asia is vitally needed.

\section{REFERENCE}

Administration of Kamchatka Region, Administration of Koryaksky Autonomous County / Kamchatka Branch of Pacific Institute of Geography, Far Eastern Branch of Russian Academy of Science (2007) Red data book of Kamchatka, vol. 2: Plants, mushrooms and thermophilic microorganisms. Kamchatsky Pechatny Dvor Publishing House, Petroavlovsk-Kamchatsky.

Administration of Primorsky Krai Krai / Institute of Biology and Soil Science, Russian Academy of Sciences Far-Eastern Branch (FEB RAS) (2008) Red data book Primorsky Krai Krai, Plants: Rare and endangered species of plants and fungi. Administration of Primorsky Krai Krai, Vladivostok.

Aizawa, M., Yoshimaru, H., Saito, H., Katsuki, T., Kawahara, T., Kitamura, K., Shi, F. \& Kaji, M. (2007) Phylogeography of a northeast Asian spruce, Picea jezoensis, inferred from genetic variation observed in organelle DNA markers. Molecular Ecology 16(16): 3393-3405.

Aizawa, M., Yoshimaru, H., Saito, H., Katsuki, T., Kawahara, T., Kitamura, K., Shi, F., Sabirov, R. \& Kaji, M. (2009) Range - wide genetic structure in a north - east Asian spruce (Picea jezoensis) determined using nuclear microsatellite markers. Journal of Biogeography 36(5): 996-1007.

Aomori Prefecture (2010) Red list of plants in Aomori prefecture. Available from: http://www.pref.aomori.lg.jp/soshiki/kankyo/shizen/files/2010-0326-1136.pdf (accessed 14 September 2017).

Biodiversity Working Group of China Council for International Cooperation on Environment and Development (2004) In: Wang, S. \& Xie, Y. (eds.) China species red list, vol. 1. Higher Education Press, Beijing.

Community of natural resources and environment conservation of Sakhalin State / Sakhalin botanical garden, Far Eastern Branch of the Russian Academy of Sciences / Biology and Soil Science Institute, Far Eastern Branch of the Russian Academy of Sciences / Social organization Club "Boomerant" of Sakhalin State (2005) Red data book of Sakhalin State: Plants. Sakhalinskoe knizhnoe izd-vo, Yuzhno-Sakhalinsk.

Demesure, B., Sodzi, N. \& Petit, R.J. (1995) A set of universal primers for amplification of polymorphic non-coding regions of mitochondrial and chloroplast DNA in plants. Molecular 
Ecology 4(1): 129-134.

Doyle, J.J. \& Doyle, J.L. (1987) A rapid DNA isolation procedure for small quantities of fresh leaf tissue. Phytochemistry Bulltein 19: 11-15.

Drummond, A.J., Suchard, M.A., Xie, D. \& Rambaut, A. (2012) Bayesian phylogenetics with BEAUti and the BEAST 1.7. Molecular Biology and Evolution 29: 1969-1973.

Earl, D.A. \& vonHoldt, B.M. (2012) STRUCTURE HARVESTER: a website and program for visualizing STRUCTURE output and implementing the Evanno method. Conservation Genetics Resources, 4(2): 359-361.

Evanno, G., Regnaut, S. \& Goudet, J. (2005) Detecting the number of clusters of individuals using the software STRUCTURE: a simulation study. Molecular Ecology 14(8): 2611-2620.

Frankham, R. (1996) Relationship of genetic variation to population size in wildlife. Conservation Biology 10(6): 1500-1508.

Frankham, R., Briscoe, D.A. \& Ballou, J.D. (2002) Introduction to conservation genetics. Cambridge University Press, Cambridge.

Fujii, N. \& Senni, K. (2006) Phylogeography of Japanese alpine plants: biogeographic importance of alpine region of Central Honshu in Japan. Taxon 55(1): 43-52.

Gizaw, A., Brochmann, C., Nemomissa, S., Wondimu, T., Masao, C.A., Tusiime, F.M., Abdi, A.A., Oxelman, B., Popp, M. \& Dimitrov, D. (2016) Colonization and diversification in the African 'sky islands' : insights from fossil - calibrated molecular dating of Lychnis (Caryophyllaceae). New Phytologist 211(2): 719-734.

Good, R. (1974) The geography of the flowering plants. Longman, London.

Goudet, J. (2002) FSTAT, version 2.9.3.2. A program to estimate and test gene diversities and fixation indices. Available from: http://www.unil.ch/izea/softwares/fstat.html.

Hall, T.A. (1999) BioEdit: a user-friendly biological sequence alignment editor and analysis program for Windows 95/98/NT. Nucleic Acids Symposium Series 41: 95-98.

Hamilton, M.B. (1999) Four primer pairs for the amplification of chloroplast intergenic regions with intraspecific variation. Molecular Ecology 8(3): 521-523.

Hara, H., Sato, K. \& Kurosawa, S. (1974) Florula of Karuizawa, central Japan. Inoue book corporation, Tokyo, $307 \mathrm{pp}$.

Hewitt, G.M. (1996) Some genetic consequences of ice ages, and their role in divergence and speciation. Biological Journal of the Linnean Society 58(3): 247-276.

Hiramatsu, M., Ii, K., Okubo, H., Huang, K.L. \& Huang, C.W. (2001) Biogeography and origin of Lilium longiflorum and L. formosanum (Liliaceae) endemic to the Ryukyu Archipelago and Taiwan as determined by allozyme diversity. American Journal of Botany 88(7): 1230-1239.

Hokkaido Prefecture (2001) Hokkaido red list (plants). Hokkaido Government, Sapporo, 10 pp. Available from: http://www.pref.hokkaido.lg.jp/ks/skn/grp/03/redlist1.pdf (accessed: 20 
August 2017).

Hokkaido Prefecture (2016) wild rare endangered species in Hokkaido. Available from: http://www.pref.hokkaido.lg.jp/ks/skn/yasei/tokutei/siteishu.htm (accessed: 19 December 2017).

Hu, L.J., Uchiyama, K., Shen, H.L. \& Ide, Y. (2010) Multiple-scaled spatial genetic structures of Fraxinus mandshurica over a riparian-mountain landscape in Northeast China. Conservation Genetics 11(1): 77-87.

Ibrahim, K.M., Nichols, R.A. \& Hewitt, G.M. (1996) Spatial patterns of genetic variation generated by different forms of dispersal during range expansion. Heredity 77(3): 282-291.

Ikeda, H., Senni, K., Fujii, N. \& Setoguchi, H. (2008) Post-glacial range fragmentation is responsible for the current distribution of Potentilla matsumurae Th. Wolf (Rosaceae) in the Japanese archipelago. Journal of Biogeography 35(5): 791-800.

Ikeda, T. (1997) Lychnis wilfordii. In: Society of nature education of Shinano (ed.) Rare and endangered species in Shinshu. Mainichi news company of Shinano, Nagano. pp.101-103.

Institute of biology and soil science, Russian academy of sciences, Far Eastern branch (1996) Flora of the Russian Far East 8. Dalnauka, Vladivostok.

Jae, C.H. \& Sungwon, S.O.N. (2016) Conservation activities on Korean rare and endemic plants -with a special reference to the Korea National Arboretum. Journal of Integrated Field Science 13: 9-12.

Jakobsson, M. \& Rosenberg, N. A. (2007) CLUMPP: a cluster matching and permutation program for dealing with label switching and multimodality in analysis of population structure. Bioinformatics 23(14): 1801-1806.

Jin, Y., He, T. \& Lu, B.R. (2003) Fine scale genetic structure in a wild soybean (Glycine soja) population and the implications for conservation. New Phytologist 159(2): 513-519.

Kadota, Y. (2017) Caryophyllaceae. In: Ohashi, H., Kadota, Y., Kihara, H., Murata, J. \& Yonekura, K. (eds.) Wild Flowers of Japan IV. Heibonsha, Tokyo, pp. 108-127.

Kikuchi, R., Pak, J.H., Takahashi, H. \& Maki, M. (2010) Disjunct distribution of chloroplast DNA haplotypes in the understory perennial Veratrum album ssp. oxysepalum (Melanthiaceae) in Japan as a result of ancient introgression. New Phytologist 188(3): 879-891.

Kikuchi, R., Pak, J.H., Takahashi, H. \& Maki, M. (2013) Pattern of population genetic structure revealed by nuclear simple sequence repeat markers in the understory perennial Veratrum album ssp. oxysepalum (Melanthiaceae) with a disjunct pattern of chloroplast DNA haplotypes. Biological Journal of the Linnean Society 108(2): 278-293.

Kim, B., Nakamura, K., Tamura, S., Lee, B. Y., Kwak, M. H., 2018. Genetic diversity and population structure of Lychnis wilfordii (Caryophyllaceae) with newly developed 17 microsatellite markers. Genes \& genomics, 1-7. 
Kim, J.M., Kennett, J.P., Park, B.K., Kim, D.C., Kim, G.Y. \& Roark, E.B. (2000) Paleoceanographic change during the last deglaciation, East Sea of Korea. Paleoceanography 15(2): 254-266.

Kokubugata, G. (2016) An integrated red list of east Asian plants. In: Korea National Arboretum \& Korea Association of Botanical Gardens and Arboreta (eds.) Sharing experience in management and education in botanical gardens and arboreta. EABGN meeting \& international symposium, Seoul, pp. 141-155

Kozhevnikov, A.E., Kozhevnikova, Z.V., Kwak,M. \& Lee, B.Y. (2015) Illustrated flora of the Southwest Primorye (Russian Far East). National Institute of Biological Resources, Incheon.

Kruckeberg, A.R. (1960) Chromosome numbers in Silene (Caryophyllaceae). II. Madroño 15: 205-215.

Langella, O. (2010) Populations 1.2.32. Available from :

http://bioinformatics.org/ tryphon/populations/ (accessed on 1 November 2011).

Lee, E. \& Nam, S. (2003) Freshwater supply by Korean rivers to the East Sea during the last glacial maximum: a review and new evidence from the Korea Strait region. Geo-Marine Letters 23(1): 1-6.

Lee, E., Kim, S. \& Nam, S. (2008). Paleo-Tsushima Water and its effect on surface water properties in the East Sea during the last glacial maximum: revisited. Quaternary International 176: $3-12$.

Lihová, J., Kudoh, H. \& Marhold, K. (2010). Genetic structure and phylogeography of a temperate-boreal herb, Cardamine scutata (Brassicaceae), in northeast Asia inferred from AFLPs and cpDNA haplotypes. American Journal of Botany 97(6): 1058-1070.

Lu, D., Lidén, M., Oxelman, B. (2001) Lychnis. In: Wu, Z., Al-Shehbaz, I.A. (eds.) Flora of China 6. Beijing, China: Science Press, Beijing/ Missouri Botanical Garden Press. St Louis. pp. $100-102$.

Maekawa, F. (1974) Origin and characteristics of Japan's flora. In: M. Numata (ed.) The flora and vegetation of Japan. Kodansha Scientific, Tokyo. pp. 33-86.

Millien - Parra, V. \& Jaeger, J.J. (1999). Island biogeography of the Japanese terrestrial mammal assemblages: an example of a relict fauna. Journal of Biogeography 26(5): 959-972.

Minato M. \& Ijiri S. (1984) The Japanese Archipelago. Iwanami-Shoten, Tokyo.

Ministry of the Environment, Government of Japan (2015) Red data book 2014-threatened wildlife of Japan-Volume 8, Plants I (vascular plants). Gyosei Corporation, Tokyo.

Ministry of the Environment, Government of Japan (2017) Ministry of the Environment red list 2017. Tokyo, Ministry of the Environment, Government of Japan. Available from: http://www.env.go.jp/press/files/jp/105449.pdf (accessed: 20 August 2017).

Morrell, P.L., Lundy, K.E. \& Clegg, M.T. (2003) Distinct geographic patterns of genetic diversity are maintained in wild barley (Hordeum vulgare ssp. spontaneum) despite migration. 
Proceedings of the National Academy of Sciences 100(19): 10812-10817.

Nagano Prefecture (2014) Red list of Nagano prefecture, vascular plants. Available from: http://www.pref.nagano.lg.jp/shizenhogo/kurashi/shizen/hogo/hogo/documents/07-1ikansoku list.pdf (accessed: 14 September 2017).

Nagano Prefecture (2017) Wild rare endangered species in Nagano. Available from: https://www.pref.nagano.lg.jp/shizenhogo/kurashi/shizen/hogo/kisyoyasei/jorei/documents/sh itei-i.pdf (accessed: 19 December 2017).

Nakamura, K., Chung, S.W., Kokubugata, G., Denda, T. \& Yokota, M. (2006) Phylogenetic systematics of the monotypic genus Hayataella (Rubiaceae) endemic to Taiwan. Journal of Plant Research 119(6): 657-661.

Nakayama, S., Inokuchi, M. \& Minamitani, T. (2006) Seeds of wild plants in Japan. Tohoku University Publisher, Miyagi, 678.

National Institute of Biological Resources (2014) Korean red list of threatened species, second edition. National Institute of Biological Resources, Incheon, 242 pp.

Nei, M., Tajima, F. \& Tateno, Y. (1983) Accuracy of estimated phylogenetic trees from molecular data. Journal of Molecular Evolution 19(2): 153-170.

Nylander, J.A.A. (2008) MrModeltest 2.3. Department of Systematic Zoology, Uppsala University. Uppsala.

Oba, T., Kato, M., Kitazato, H., Koizumi, I., Omura, A., Sakai, T. \& Takayama, T. (1991) Paleoenvironmental changes in the Japan Sea during the last 85,000 years. Paleoceanography 6(4): 499-518.

Oba, T. \& Irino, T. (2012). Sea level at the last glacial maximum, constrained by oxygen isotopic curves of planktonic foraminifera in the Japan Sea. Journal of Quaternary Science 27(9): 941-947.

Ohsima, K. (1990) The history of straits around the Japanese Islands in the late-Quaternary. The Quaternary Research (Daiyonki-Kenkyu) 29(3): 193-208.

Okaura, T., Quang, N.D., Ubukata, M. \& Harada, K. (2007) Phylogeographic structure and late Quaternary population history of the Japanese oak Quercus mongolica var. crispula and related species revealed by chloroplast DNA variation. Genes \& Genetic Systems 82(6): $465-477$.

Oxelman, B., Lidén, M. \& Berglund, D. (1997) Chloroplastrps16 intron phylogeny of the tribe Sileneae (Caryophyllaceae). Plant Systematics and Evolution 206(1-4): 393-410.

Popp, M., Gizaw, A., Nemomissa, S., Suda, J. \& Brochmann, C. (2008) Colonization and diversification in the African 'sky islands' by Eurasian Lychnis L.(Caryophyllaceae). Journal of Biogeography 35(6): 1016-1029.

Pritchard, J.K., Stephens, M., Donnelly, P. (2000) Inference of population structure using multilocus 
genotype data. Genetics 155: 945-959.

Pritchard, J.K., Wen, W., Falush, D. (2010) Documentation for Structure Software: version 2.3. University of Chicago, Department of Human Genetics, Chicago.

Qi, X.S., Chen, C., Comes, H.P., Sakaguchi, S., Liu, Y.H., Tanaka, N., Sakio, H. \& Qiu, Y.X. (2012) Molecular data and ecological niche modelling reveal a highly dynamic evolutionary history of the East Asian Tertiary relict Cercidiphyllum (Cercidiphyllaceae). New Phytologist 196(2): 617-630.

Rambaut, A., Drummond, A.J. \& Suchard, M. (2013) Tracer v1.6: MCMC Trace Analysis Package. Institute of Evolutionary Biology, University of Edinburgh, UK. Available from: http://tree.bio.ed.ac.uk/software/tracer/ (accessed: 20 August 2017).

Rambaut, A. (2014) FigTree 1.4.2 software, Institute of Evolutionary Biology, Univ. Edinburgh. Available from: http://tree.bio.ed.ac.uk/software/figtree/ (accessed: 20 August 2017).

Richardson, J.E., Pennington, R.T., Pennington, T.D. \& Hollingsworth, P.M. (2001) Rapid diversification of a species-rich genus of neotropical rain forest trees. Science 293(5538): $2242-2245$.

Rosenberg, N.A. (2004) DISTRUCT: a program for the graphical display of population structure. Molecular Ecology Resources 4(1): 137-138.

Shaw, J., Lickey, E.B., Schilling, E.E. \& Small, R.L. (2007) Comparison of whole chloroplast genome sequences to choose noncoding regions for phylogenetic studies in angiosperms: the tortoise and the hare III. American Journal of Botany 94(3): 275-288.

Shimizu, T. (1997) Flora of Nagano prefecture. Shinano Mainichi Shinbunsha, Nagano.

Small, R.L., Ryburn, J.A., Cronn, R.C., Seelanan, T. \& Wendel, J.F. (1998) The tortoise and the hare: choosing between noncoding plastome and nuclear Adh sequences for phylogeny reconstruction in a recently diverged plant group. American Journal of Botany 85(9): 1301-1315.

Sugawara, S. (1975) Flora of Sakhalin 2. Kokusho kankokai, Tokyo.

Swofford, D.L. (2002) PAUP*: phylogenetic analysis using parsimony, version 4.0b10. Sinauer Associates, Sunderland. Available from: http://paup.sc.fsu.edu/ (accessed: 20 August 2017).

Taberlet, P., Gielly, L., Pautou, G. \& Bouvet, J. (1991) Universal primers for amplification of three non-coding regions of chloroplast DNA. Plant Molecular Biology 17: 1105-1109.

Takhtajan, A. (1986) Floristic regions of the world. University of California Press, Berkeley.

Tamura, S., Fujita, H., Nishikawa, Y., Shimamura, T., Inagawa, H., Takada, J. \& Nakamura, K. (2016) Ecological survey and genetic analysis for the conservation of the designated endangered plant in Hokkaido, Lychnis wilfordii (Caryophyllaceae). Bulletin of Japan Association of Botanical Gardens 51, 33-43.

Tang, C.Q. \& Ohsawa, M. (2002) Tertiary relic deciduous forests on a humid subtropical mountain, 
Mt. Emei, Sichuan, China. Folia Geobotanica 37(1): 93-106.

Tremetsberger, K., Stuessy, T.F., Samuel, R.M., Baeza, C.M. \& Fay, M.F. (2003) Genetics of colonization in Hypochaeris tenuifolia (Asteraceae, Lactuceae) on Volcán Lonquimay, Chile. Molecular Ecology 12(10): 2649-2659.

Tsukada, M. (1983) Vegetation and climate during the last glacial maximum in Japan. Quaternary Research 19(2): 212-235.

Ullbors, M. (2008) East Asian Lychnis - phylogeny and systematics. Degree project in biology, University of Uppsala.

Washitani, I., Ishihama, F., Matsumura, C., Nagai, M., Nishihiro, J. \& Nishihiro, M. (2005) Conservation ecology of Primula sieboldii: synthesis of information toward the prediction of the genetic/demographic fate of a population. Plant Species Biology 20(1): 3-15.

Whipple, I.G., Barkworth, M.E. \& Bushman, B.S. (2007) Molecular insights into the taxonomy of Glyceria (Poaceae: Meliceae) in North America. American Journal of Botany 94(4): $551-557$.

Wu, Z. \& Wu, S. (1996) A proposal for a new floristic kingdom (realm): the E. Asiatic Kingdom, its delineation and characteristics. Floristic characteristics and diversity of East Asian plants: proceedings of the first international symposium of floristic characteristics and diversity of East Asian plants. China Higher Education Press, Beijing. pp. 3-42.

Yasuda, Y. (1984). Oscillations of climatic and oceanographic conditions since the last glacial age in Japan. The Evolution of the East Asian Environment 1: 397-413. 
Table 1. Geographic and genetic characteristics of Lychnis wilfordii populations from seven regions of four countries, Japan, Korea, northeastern China and Russian Far East.

\begin{tabular}{|c|c|c|c|c|c|c|c|c|c|c|c|}
\hline Country & Region & $\begin{array}{l}\text { Population } \\
\text { No. }\end{array}$ & Locality & $\begin{array}{l}\text { Geographic coordinate, } \\
\text { altitude }\end{array}$ & $\begin{array}{l}\text { Number of } \\
\text { individuals }\end{array}$ & Voucher (herbarium) & $\begin{array}{l}\text { Wild population, } \\
\text { cultivation, herbarium }\end{array}$ & $N_{\mathrm{A}}$ & $R \mathrm{~s}$ & $H \mathrm{~s}$ & $F_{\text {IS }}$ \\
\hline \multirow[t]{11}{*}{ Japan } & Hokkaido & 1 & Abira & $\begin{array}{l}\text { N42 } 4 X^{\circ} X X^{\prime \prime} \\
\text { E141 }\end{array}$ & 4 & SayaTamura63-66 (SAPT) & Wild population & 1.06 & 1.07 & 0.03 & -0.50 \\
\hline & & 2 & Abira & $\begin{array}{l}\text { N42ํX'XX" } \\
\text { E141 }{ }^{\circ} 5 X^{\prime} X X^{\prime \prime}, 36 m\end{array}$ & 10 & SayaTamura67-76 (SAPT) & Wild population & 1.00 & 1.00 & 0.00 & - \\
\hline & & 3 & Abira & $\begin{array}{l}\text { N42 } 42^{\circ} X X " \\
\text { E141 }{ }^{\circ} 5 X^{\prime} X X ", 45 m\end{array}$ & 5 & SayaTamura77-81 (SAPT) & Wild population & 1.06 & 1.07 & 0.02 & 1.00 \\
\hline & & 4 & Abira & $\begin{array}{l}\mathrm{N} 42^{\circ} 4 X^{\prime} X X^{\prime \prime} \\
\text { E141 }{ }^{\circ} 5 X^{\prime} X X^{\prime \prime}, 40 \mathrm{~m}\end{array}$ & 7 & SayaTamura82-88 (SAPT) & Wild population & 1.00 & 1.00 & 0.00 & - \\
\hline & & 5 & Hidaka & $\begin{array}{l}\mathrm{N} 42^{\circ} 2 X^{\prime} X X^{\prime \prime} \\
\text { E142 }\end{array}$ & 8 & SayaTamura125-132 (SAPT) & Wild population & 1.06 & 1.00 & 0.03 & 0.19 \\
\hline & & 6 & Hidaka & $\begin{array}{l}\mathrm{N} 42^{\circ} 2 X^{\prime} X X^{\prime \prime} \\
\text { E142 }\end{array}$ & 7 & SayaTamura152-158 (SAPT) & Cultivation & 1.00 & 1.00 & 0.00 & - \\
\hline & & 7 & Shin Hidaka & $\begin{array}{l}\text { N422ㅈ'XX" } \\
\text { E142 } 12^{\circ} X^{\prime} X^{\prime \prime}, 9 \mathrm{~m}\end{array}$ & 5 & SayaTamura120-124 (SAPT) & Wild population & 1.00 & 1.00 & 0.00 & - \\
\hline & & 8 & Shin Hidaka & $\begin{array}{l}\text { N42 } 2 X^{\prime} X X^{\prime \prime} \\
\text { E } 142^{\circ} 1 X^{\prime} X X^{\prime \prime}, 51 \mathrm{~m}\end{array}$ & 2 & SayaTamura873-874 (SAPT) & Wild population & 1.00 & - & - & - \\
\hline & & 9 & Hidaka & $\begin{array}{l}\mathrm{N} 42^{\circ} 2 \mathrm{X}^{\prime} \mathrm{XX} " \\
\mathrm{E} 142^{\circ} 0 \mathrm{XXX}^{\prime}, 15 \mathrm{~m}\end{array}$ & 24 & $\begin{array}{l}\text { SayaTamura636, 645, 654, 660, } \\
665,677,687,694,702,713, \\
724,740,747,757,766,775, \\
782,793,800,815,827,840, \\
857,869 \text { (SAPT) }\end{array}$ & Wild population & 1.12 & 1.06 & 0.01 & $0.65 * *$ \\
\hline & & 10 & Shin Hidaka & $\begin{array}{l}\mathrm{N} 42^{\circ} 2 X^{\prime} X X " \\
\text { E142 }\end{array}$ & 31 & SayaTamura89-1 19 (SAPT) & Wild population & 1.29 & 1.12 & 0.05 & $0.62 * *$ \\
\hline & & & & & 103 & & & 1.71 & 1.49 & 0.14 & $0.92 * *$ \\
\hline
\end{tabular}




\begin{tabular}{|c|c|c|c|c|c|c|c|c|c|c|}
\hline \\
\hline Aomori & 11 & Hachinohe & - & 1 & SayaTamura871 (SAPT) & Herbarium & 1.00 & - & - & - \\
\hline \multirow[t]{8}{*}{ Nagano } & 12 & Suwa & $\begin{array}{l}\mathrm{N} 36^{\circ} 0 X^{\prime} X X^{\prime \prime} \\
\text { E138 } 0 X^{\prime} X X^{\prime \prime}, 1049 m\end{array}$ & 8 & SayaTamura402-409 (SAPT) & Wild population & $1.06 \dagger$ & 1.07 & 0.03 & -0.56 \\
\hline & 13 & Ina & $\begin{array}{l}\mathrm{N} 35^{\circ} 5 X^{\prime} X X^{\prime \prime} \\
\text { E138 } 0 X^{\circ} X X^{\prime \prime}, 1272 \mathrm{~m}\end{array}$ & 8 & SayaTamura410-417 (SAPT) & Wild population & $1.50 \dagger$ & 1.40 & 0.14 & $0.42 * *$ \\
\hline & 14 & Yatsugatake & - & 10 & SayaTamura172-184 (SAPT) & Cultivation & $1.06 \dagger$ & 1.05 & 0.02 & 0.64 \\
\hline & 15 & Yatsugatake & $\begin{array}{l}\text { N36 } 36^{\circ} X^{\prime} X X^{\prime \prime} \\
\text { E137 } 4 X^{\circ} X X^{\prime \prime}, 1515 \mathrm{~m}\end{array}$ & 15 & SayaTamura347-361 (SAPT) & Cultivation & $1.00 \dagger$ & 1.00 & 0.00 & - \\
\hline & 16 & $\begin{array}{l}\text { Yatsugatake, } \\
\text { Hara }\end{array}$ & $\begin{array}{l}\mathrm{N} 35^{\circ} 5 X^{\prime} X X^{\prime \prime} \\
\text { E138 } 1 X^{\circ} X X^{\prime \prime}, 1278 m\end{array}$ & 14 & SayaTamura362-401 (SAPT) & $\begin{array}{l}\text { Wild population and } \\
\text { cultivation }\end{array}$ & $1.25 \dagger$ & 1.18 & 0.06 & $1.00 * *$ \\
\hline & 17 & Karuizawa & $\begin{array}{l}\text { N36º' } X^{\prime} X X^{\prime \prime} \\
\text { E138 } 3 X^{\circ} X X^{\prime \prime}, 951 m\end{array}$ & 2 & SayaTamura418-419 (SAPT) & Cultivation & $1.13 \dagger$ & - & - & - \\
\hline & 18 & Karuizawa & - & 3 & $505292,431172,215283$ (TNS) & Herbarium & $1.81 \dagger$ & - & - & - \\
\hline & & & & 60 & & & 2.88 & 1.80 & 0.19 & $0.86^{* *}$ \\
\hline \multirow[t]{4}{*}{ Gangwon-do } & 19 & Inje & $\begin{array}{l}\mathrm{N} 38^{\circ} 1 \mathrm{X}^{\prime} \mathrm{XX} \\
\mathrm{E} 128^{\circ} 0 \mathrm{X}^{\prime} \mathrm{XX}\end{array}$ & 30 & NIBR1-30 (KB) & Wild population & 2.00 & 1.70 & 0.20 & $0.34 * *$ \\
\hline & 20 & Inje & $\begin{array}{l}\mathrm{N} 38^{\circ} 1 \mathrm{X}^{\prime} \mathrm{XX} \\
\mathrm{E} 128^{\circ} 0 \mathrm{X}^{\prime} \mathrm{XX}\end{array}$ & 13 & NIBR31-43 (KB) & Wild population & 2.47 & 1.59 & 0.29 & $0.47 * *$ \\
\hline & 21 & Pyeongchang & 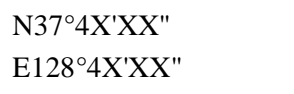 & 22 & NIBR44-65 (KB) & Wild population & 2.29 & 1.91 & 0.32 & 0.04 \\
\hline & & & & 65 & & & 4.35 & 3.72 & 0.60 & $0.71 * *$ \\
\hline
\end{tabular}




\begin{tabular}{|c|c|c|c|c|c|c|c|c|c|c|c|}
\hline \multirow[t]{11}{*}{ China } & Jilin & 22 & Mt. Changbai & $\begin{array}{l}\mathrm{N} 42^{\circ} 2 \mathrm{X}^{\prime} \mathrm{X}^{\prime \prime} \\
\mathrm{E} 128^{\circ} 2 \mathrm{X}^{\prime} \mathrm{X}^{\prime \prime}, 765 \mathrm{~m}\end{array}$ & 6 & $\begin{array}{l}\text { SayaTamura875-879, } 883 \\
\text { (SAPT) }\end{array}$ & Wild population & 2.65 & 2.47 & 0.38 & $0.17 *$ \\
\hline & & 23 & Mt. Changbai & $\begin{array}{l}\mathrm{N} 42^{\circ} 2 \mathrm{X}^{\prime} \mathrm{XX} " \\
\mathrm{E} 128^{\circ} 6 \mathrm{X}^{\prime} \mathrm{XX} ", 750 \mathrm{~m}\end{array}$ & 2 & SayaTamura880-881 (SAPT) & Wild population & 1.94 & - & - & - \\
\hline & & 24 & Helong & - & 5 & SayaTamura1044-1048 (SAPT) & Wild population & 2.65 & 2.42 & 0.51 & $0.29 * *$ \\
\hline & & 25 & Dunhua & - & 5 & SayaTamura1049-1053 (SAPT) & Wild population & 2.06 & 2.09 & 0.41 & $0.77 * *$ \\
\hline & & 26 & Dunhua & - & 5 & SayaTamura1054-1058 (SAPT) & Wild population & 1.94 & 1.86 & 0.30 & $0.54 * *$ \\
\hline & & 27 & Dunhua & - & 5 & SayaTamura1059-1063 (SAPT) & Wild population & 2.47 & 2.39 & 0.52 & $0.66^{* *}$ \\
\hline & & 28 & Yanbian & - & 5 & SayaTamura1064-1068 (SAPT) & Wild population & 2.65 & 2.56 & 0.53 & $0.29 * *$ \\
\hline & & 29 & Dunhua & - & 5 & SayaTamura1069-1073 (SAPT) & Wild population & 1.76 & 1.62 & 0.28 & $0.75^{* *}$ \\
\hline & & 30 & Yanji & $\begin{array}{l}\mathrm{N} 42^{\circ} 5 \mathrm{X}^{\prime} \mathrm{XX} " \\
\mathrm{E} 128^{\circ} 2 \mathrm{X}^{\prime} \mathrm{XX}\end{array}$ & 30 & NIBR66-95 (KB) & Wild population & 3.76 & 2.32 & 0.41 & $0.46^{* *}$ \\
\hline & & 31 & Yanji & $\begin{array}{l}\mathrm{N} 42^{\circ} 1 \mathrm{X}^{\prime} \mathrm{XX} " \\
\mathrm{E} 127^{\circ} 4 \mathrm{X}^{\prime} \mathrm{XX}\end{array}$ & 30 & NIBR96-125 (KB) & Wild population & 4.35 & 2.44 & 0.41 & $0.30^{* *}$ \\
\hline & & & & & 98 & & & 8.71 & 5.72 & 0.60 & $0.59 * *$ \\
\hline \multirow[t]{3}{*}{ Russia } & $\begin{array}{l}\text { South } \\
\text { Primorsky } \\
\text { Krai }\end{array}$ & 32 & & $\begin{array}{l}\text { N } 42^{\circ} 4 X^{\prime} X X^{\prime \prime} \\
\text { E } 130^{\circ} 5 X^{\prime} X X^{\prime \prime}, 13 m\end{array}$ & 25 & $\begin{array}{l}\text { KohNakamura16343-16367 } \\
\text { (SAPT) }\end{array}$ & Wild population & 2.13 & 1.47 & 0.16 & $0.73^{* *}$ \\
\hline & & 33 & & $\begin{array}{l}\text { N } 42^{\circ} 4 X^{\prime} X X^{\prime \prime} \\
\text { E } 131^{\circ} 1 X^{\prime} X X^{\prime \prime}, 64 m\end{array}$ & 11 & $\begin{array}{l}\text { KohNakamura16313-16324 } \\
\text { (SAPT) }\end{array}$ & Wild population & 3.00 & 2.51 & 0.55 & $0.44 * *$ \\
\hline & & 34 & & $\begin{array}{l}\mathrm{N} 43^{\circ} 1 \mathrm{X}^{\prime} \mathrm{XX} " \\
\mathrm{E} 131^{\circ} 5 \mathrm{X}^{\prime} \mathrm{XX}, 49 \mathrm{~m}\end{array}$ & 1 & KohNakamura14441 (SAPT) & Wild population & 1.00 & - & - & - \\
\hline
\end{tabular}


$\mathrm{N} 42^{\circ} 2 \mathrm{X}^{\prime} \mathrm{XX}$

$\mathrm{E} 132^{\circ} 2 \mathrm{X}^{\prime} \mathrm{XX}$

$\mathrm{N} 44^{\circ} 4 \mathrm{X}^{\prime} \mathrm{XX}$

North
Primorsk

Krai
Wild population

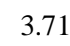

2.53

0.49

$0.5 * *$

Wild population

Wild population

3.06

1.76

(1.76.

4.29

3.68

5.76

4.69

0.60

$0.71^{* *}$

2.06

1.94

0.36
36

38
E $136^{\circ} 1 X^{\prime} X X^{\prime \prime}, 56 m$

$\mathrm{N} 44^{\circ} 5 \mathrm{X}^{\prime} \mathrm{XX} "$
$\mathrm{E} 136^{\circ} 3 \mathrm{X}^{\prime} \mathrm{XX} ", 23 \mathrm{~m}$
$\mathrm{~N} 45^{\circ} 1 \mathrm{X}^{\prime} \mathrm{XX} "$

E136 $3 X^{\prime} X X^{\prime \prime}, 149 m$
20

KohNakamura16255-16264 (SAPT)

14

KohNakamura14153-14166 (SAPT)

49

KohNakamura14369-14393

(SAPT)
$0.80 * *$

$06 \quad 2.48 \quad 0.45 \quad 0.72 * *$

$1.50 \quad 0.14 \quad 0.63 * *$

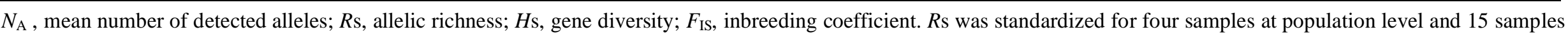
at region level. $\dagger N_{\mathrm{A}}$ and $H$ s calculate with 16 markers excluding an unamplified marker. $* P \leq 0.05, * * P \leq 0.01$. 
Table 2. Characteristics of 17 microsatellite markers developed for Lychnis wilfordii (Kwak et al., in preparation).

\begin{tabular}{lcccc}
\hline Locus & Repeat motif & Size range & $\begin{array}{c}\text { Annealing temperature } \\
\left(\mathrm{Ta},{ }^{\circ} \mathrm{C}\right)\end{array}$ & Fluorescent dye \\
\hline Lw06† & AT & $132-199$ & $60-55^{*}$ & 6-FAM \\
Lw07† & GT & $380-394$ & $60-55^{*}$ & NED \\
Lw08 $\dagger$ & CA & $409-419$ & 55 & PET \\
Lw16 & AG & $207-243$ & 55 & 6-FAM \\
Lw21 $\dagger$ & AG & $249-280$ & 52 & VIC \\
Lw25 & AC & $394-404$ & 55 & PET \\
Lw26 & AC & $392-402$ & 55 & PET \\
Lw37 & TG & $236-274$ & $65-60 *$ & VIC \\
Lw38 & TG & $180-208$ & $65-60^{*}$ & 6-FAM \\
Lw52 & ATC & $218-254$ & 55 & VIC \\
Lw57 & ACA & $386-424$ & 55 & PET \\
Lw59 & TTC & $329-374$ & 55 & NED \\
Lw68 $\dagger$ & CT & $245-265$ & 50 & NED \\
Lw69 & AG & $200-216$ & 55 & 6-FAM \\
Lw80 & AG & $221-239$ & $60-55^{*}(1 \mathrm{stPCR}) /$ & NED \\
Lw83 $†$ & GT & $370-392$ & $55(2 \mathrm{ndPCR})$ & NED \\
Lw91 & TA & $304-316$ & 55 & VIC \\
\hline
\end{tabular}

* Indicates touchdown PCR. The annealing temperature of the first 10 cycles was decreased $0.5{ }^{\circ} \mathrm{C}$ per cycle. $†$ Reverse primers attached with PIG-tail sequence (5'-GTTTCTT-3') to promote full adenylation of PCR fragments. 
Table 3. Characteristics of eight cpDNA markers for sequencing.

\begin{tabular}{|c|c|c|c|c|c|}
\hline Region & Primer name & & Primer sequence & $\begin{array}{l}\text { Annealing } \\
\text { temperature } \\
\left(\mathrm{Ta},{ }^{\circ} \mathrm{C}\right)\end{array}$ & Reference \\
\hline \multirow[t]{2}{*}{$r p s F-r p s R 2$} & $\mathrm{rpsF}$ & $\mathrm{F}$ & GTGGTAGAAAGCAACGTGCGACTT & 50 & Oxelman et al., 1997 \\
\hline & $\operatorname{rpsR} 2$ & $\mathrm{R}$ & TCGGGATCGAACATCAATTGCAAC & & \\
\hline \multirow[t]{2}{*}{$\operatorname{trn} S-\operatorname{trn} G$} & $\operatorname{trnS}$ & $\mathrm{F}$ & GCCGCTTTAGTCCACTCAGC & 50 & Hamilton, 1999 \\
\hline & $\operatorname{trnG}$ & $\mathrm{R}$ & GAACGAATCACACTTTTACCAC & & \\
\hline \multirow[t]{2}{*}{$\operatorname{trnLc}-\operatorname{trnFf}$} & $\operatorname{trnLc}$ & $\mathrm{F}$ & CGAAATCGGTAGACGCTACG & 58 & Taberlet et al., 1991 \\
\hline & $\operatorname{trnFf}$ & $\mathrm{R}$ & ATTTGAACTGGTGACACGAG & & \\
\hline \multirow[t]{2}{*}{$\operatorname{trn} S-\operatorname{trnfM}$} & $\operatorname{trnS}$ & $\mathrm{F}$ & GAGAGAGAGGGATTCGAACC & 56 & Demesure et al., 1995 \\
\hline & $\operatorname{trnfM}$ & $\mathrm{R}$ & CATAACCTTGAGGTCACGGG & & \\
\hline \multirow[t]{2}{*}{$a t p B 2 F-r b c L 2 R$} & atpB2F & $\mathrm{F}$ & ACTTAGAGGAGCTCCCGTGTCAATC & 56 & Nakamura et al., 2006 \\
\hline & $\operatorname{rbcL2R}$ & $\mathrm{R}$ & CACAGTTGTCCATGTACCAGTAGAAG & & \\
\hline \multirow[t]{2}{*}{$p s b J-P e t A$} & psbJ & $\mathrm{F}$ & ATAGGTACTGTARCYGGTATT & 58 & Shaw et al., 2007 \\
\hline & PetA & $\mathrm{R}$ & AACARTTYGARAAGGTTCAATT & & \\
\hline \multirow[t]{2}{*}{ rpL16F71-rpL16R1516 } & $\mathrm{rpL} 16 \mathrm{~F} 71$ & $\mathrm{~F}$ & GCTATGCTTAGTGTGTGACTCGTTG & 58 & Small et al., 1998 \\
\hline & rpL16R1516 & $\mathrm{R}$ & СССТTCATTCTTCCTCTATGTTG & & \\
\hline \multirow[t]{2}{*}{$\operatorname{trnC}-\mathrm{PetN1r}$} & $\operatorname{trnC}$ & $\mathrm{F}$ & CCAGTTCAAATCTGGGTGTC & 58 & Whipple et al., 2007 \\
\hline & PetN1r & $\mathrm{R}$ & CCCAAGCAAGACTTACTATATCC & & \\
\hline
\end{tabular}


Table 4. Pairwise genetic distance $D A$ among six regions.

\begin{tabular}{|c|c|c|c|c|c|c|}
\hline Region & Hokkaido & Nagano & Gangwon-do & Jilin & $\begin{array}{c}\text { South Primorsky } \\
\text { Krai }\end{array}$ & $\begin{array}{c}\text { North Primorsky } \\
\text { Krai }\end{array}$ \\
\hline Hokkaido & 0.00 & & & & & \\
\hline Nagano & 0.70 & 0.00 & & & & \\
\hline Gangwon-do & 0.83 & 0.67 & 0.00 & & & \\
\hline Jilin & 0.67 & 0.81 & 0.58 & 0.00 & & \\
\hline $\begin{array}{l}\text { South Primorsky } \\
\text { Krai }\end{array}$ & 0.54 & 0.64 & 0.54 & 0.51 & 0.00 & \\
\hline $\begin{array}{l}\text { North Primorsky } \\
\text { Krai }\end{array}$ & 0.34 & 0.74 & 0.62 & 0.53 & 0.39 & 0.00 \\
\hline
\end{tabular}


bioRxiv preprint doi: https://doi.org/10.1101/857227; this version posted February 6, 2020. The copyright holder for this preprint (which was not certified by peer review) is the author/funder. All rights reserved. No reuse allowed without permission.

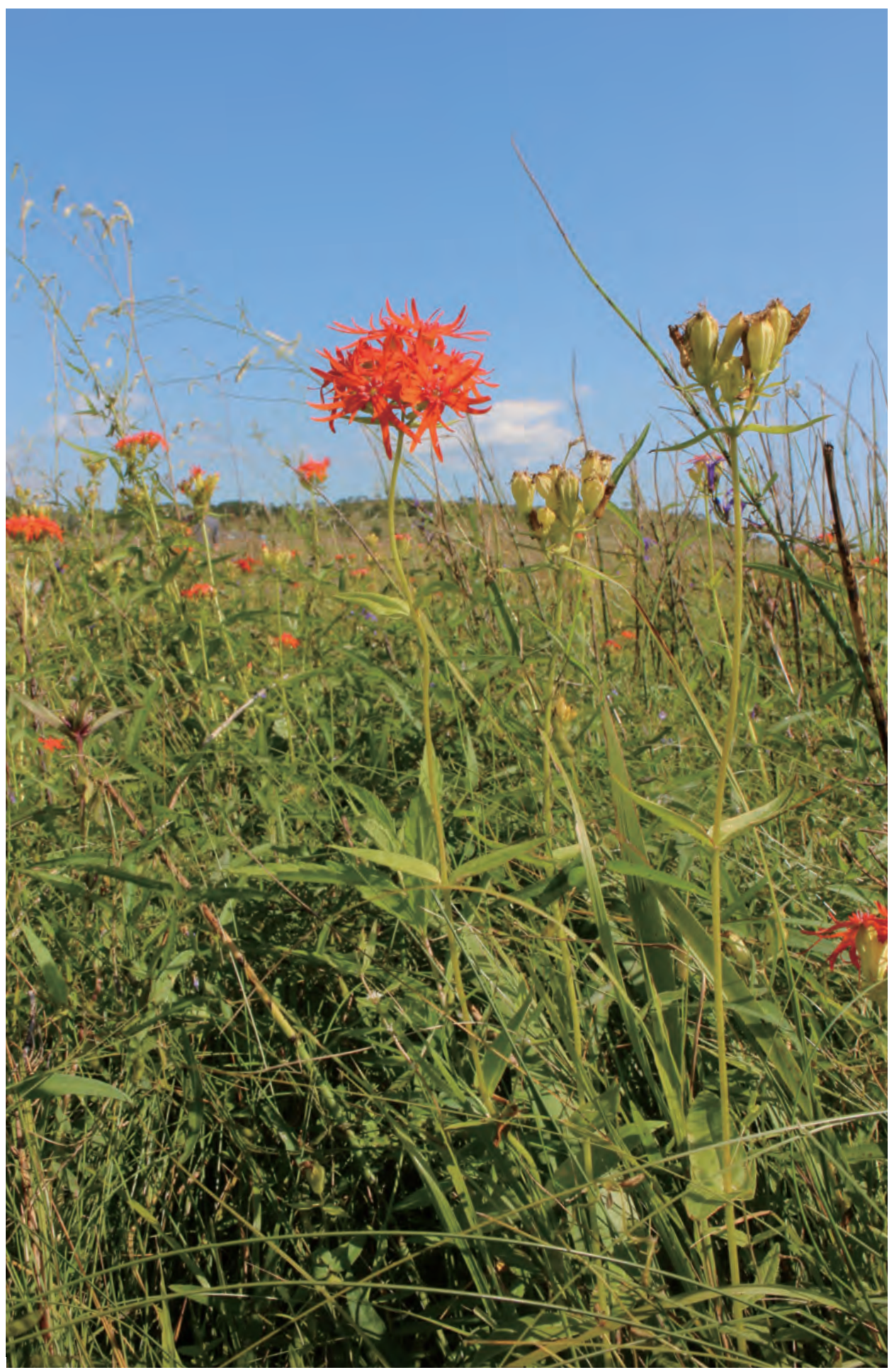

Figure 1. Lychnis wilfordii in a habitat in Russia Far East (Sep. 3, 2017). 
bioRxiv preprint doi: https://doi.org/10.1101/857227; this version posted February 6, 2020. The copyright holder for this preprint (which was not certified by peer review) is the author/funder. All rights reserved. No reuse allowed without permission.

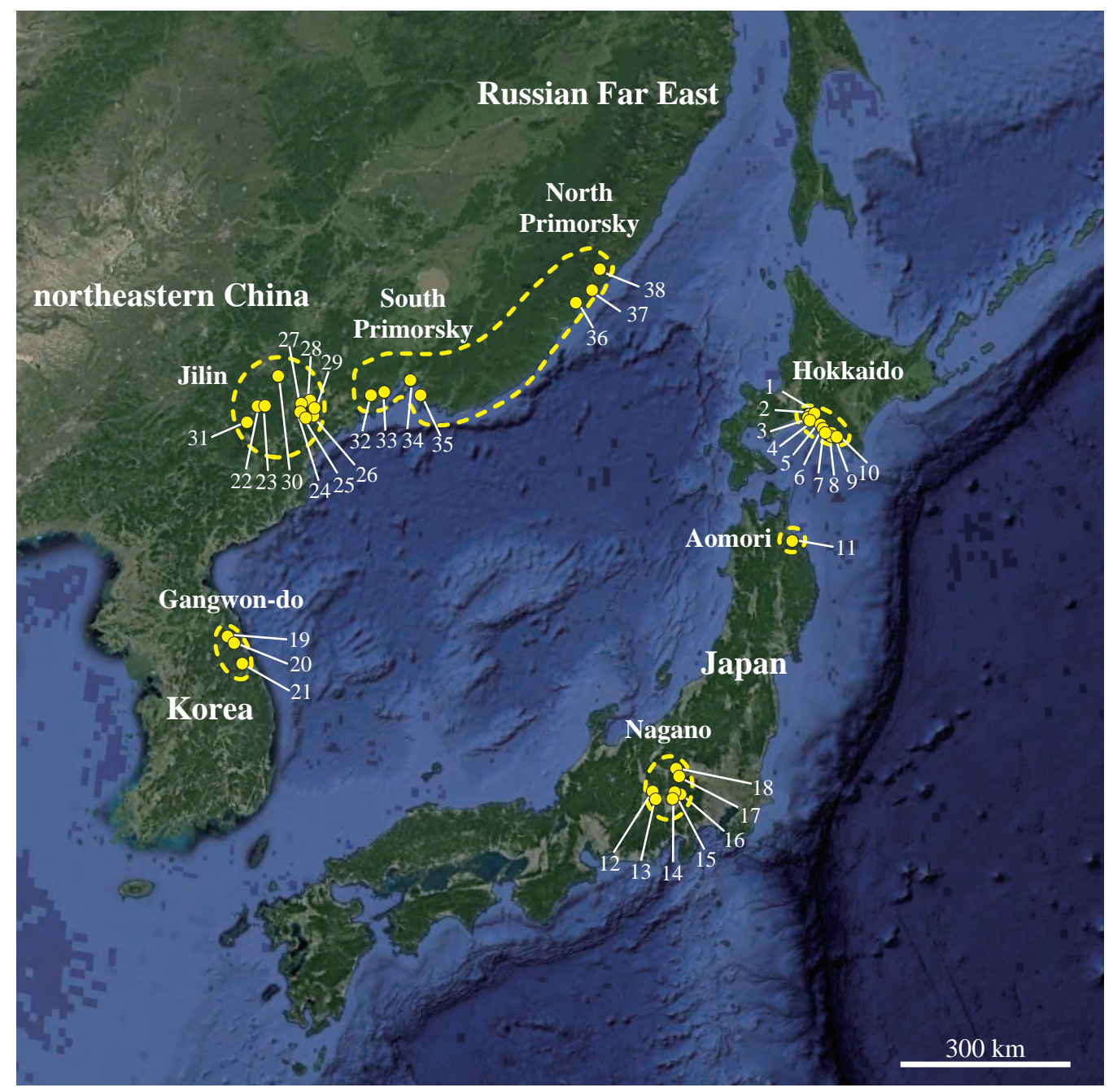

Figure 2. Species range and collection sites of Lychnis wilfordii. Circles of broken line show the species range and small filled circles show the sampling populations. For the population numbers (1-38), see Table 1. 

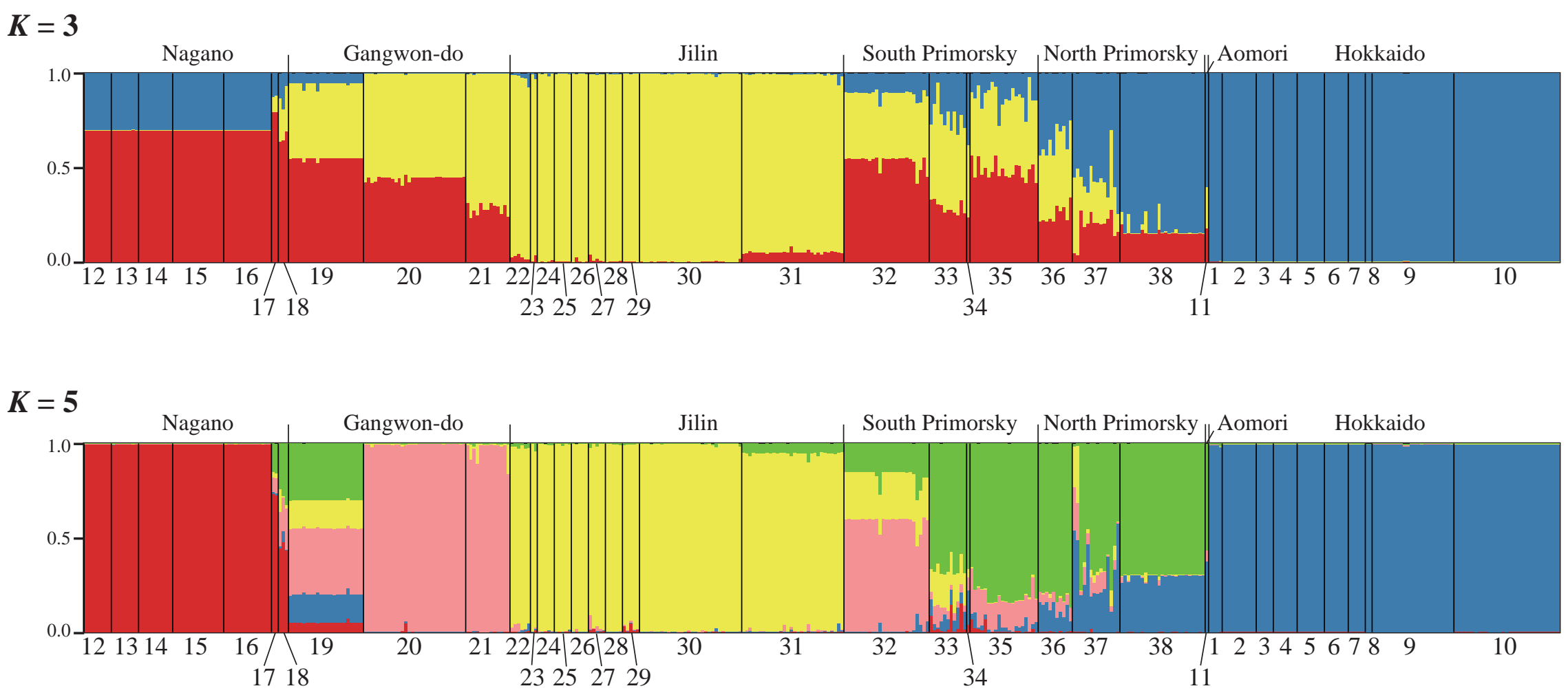

Figure 3. Results of the Bayesian clustering analyses for Lychnis wilfordii based on nSSR data. Bar plots show the membership coefficients Q. Each individual is represented by a vertical line partitioned into coloured components corresponding to its mean membership coefficients over 20 runs of the STRUCTURE analysis. For the population numbers (1-38), see Table 1. 


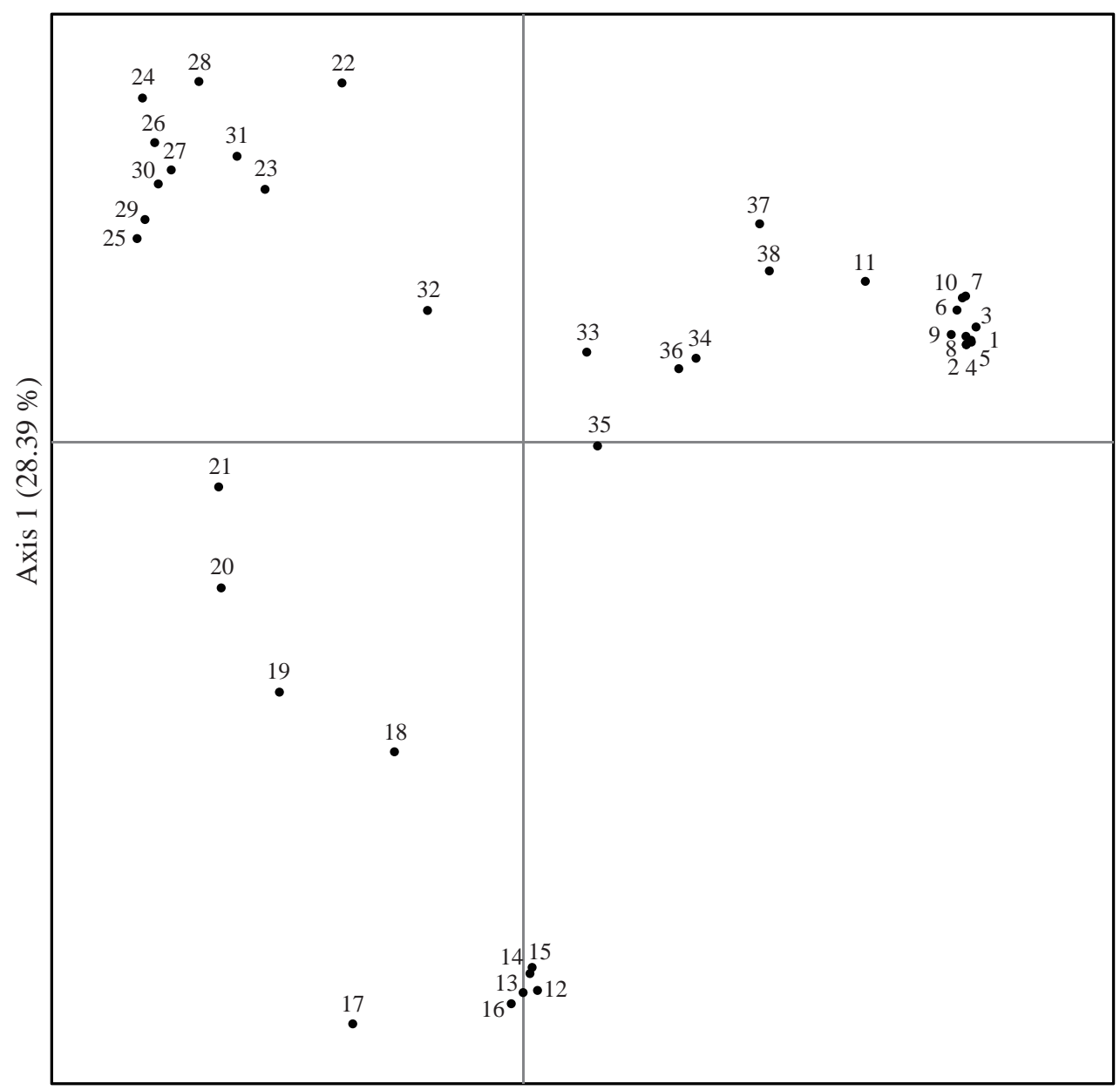

Axis $2(27.43 \%)$

Figure 4. Plots of principal coordinates analysis (PCoA) of Lychnis wilfordii using the nSSR data, based on $D_{\mathrm{A}}$ genetic distance among populations. Populations 1-10 are from Hokkaido; 11 is from Aomori; 12-18 are from Nagano; 19-21 from Gangwon-do; 22-31 from Jilin; 32-35 from south Primorsky; 36-38 from north Primorsky. For details of the populations, see Table 1. 


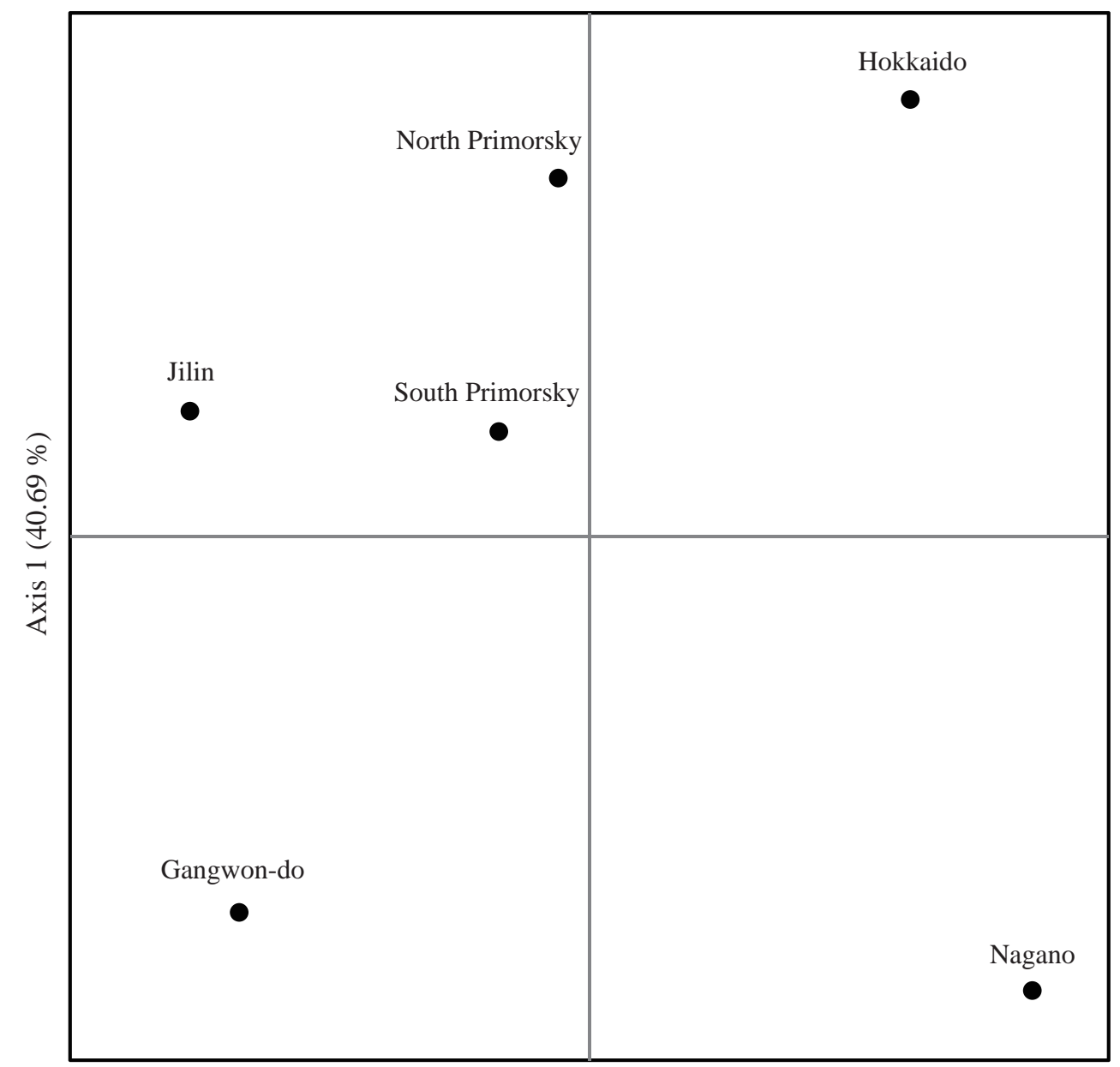

Axis 2 (35.19\%)

Figure 5. Plots of principal coordinates analysis (PCoA) of Lychnis wilfordii using the nSSR data, based on $D_{\mathrm{A}}$ genetic distanve among six regions. Aomori region was excluded due to $n=1$. For details of the regions, see Table 1 . 


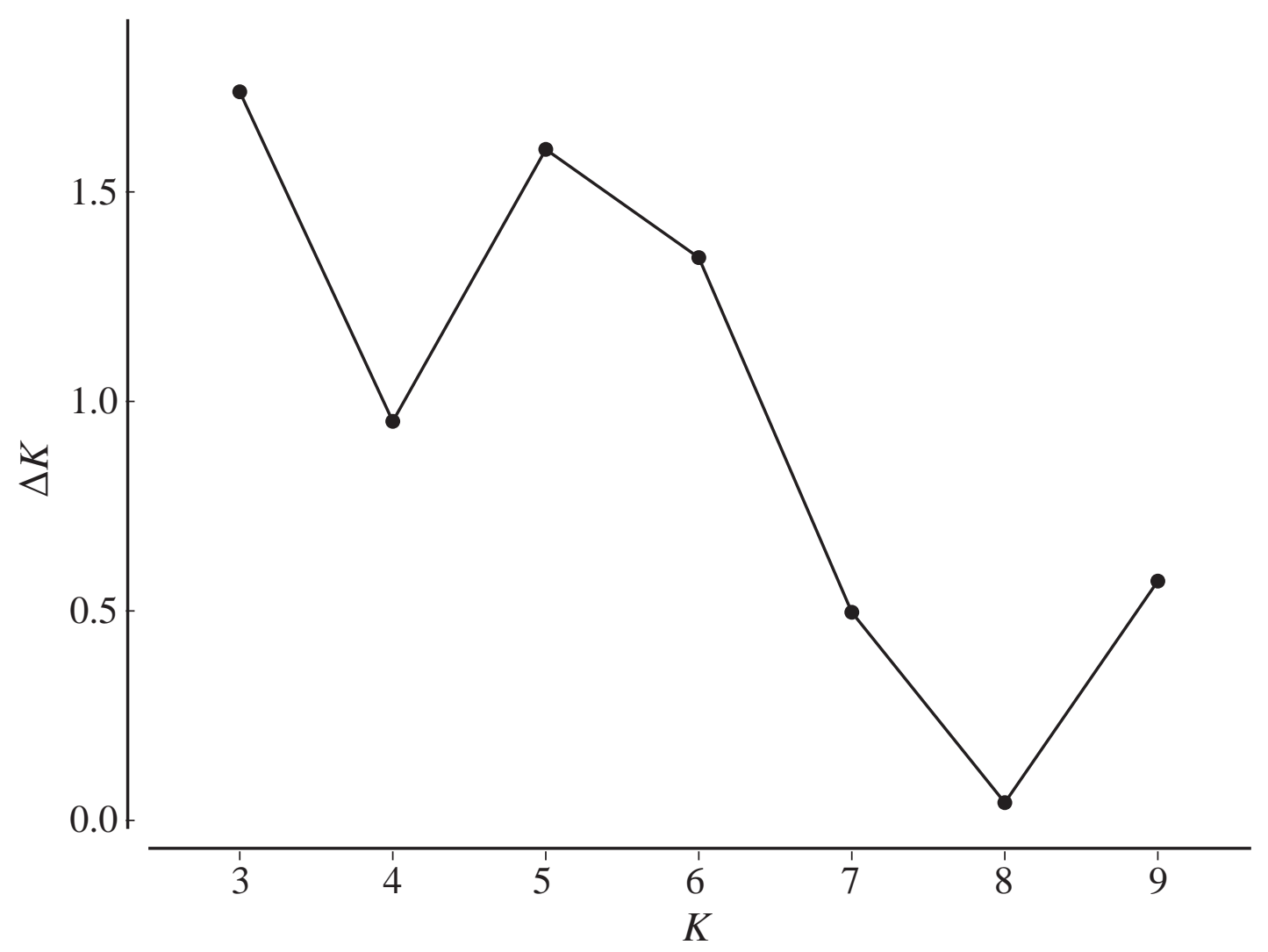

Figure S. Results of the Bayesian clustering analyses of Lychnis wilfordii based on the nSSR data. Plot of the statistic $\Delta K$ ( $K$, number of clusters) based on the second-order rate of change of $\ln P(D)$ with respect to $K$. Bar plots showing the membership coefficients $Q$ at $K=3$ and 6 are provided in Fig. 3 . 